MARTYNA JACKIEWICZ (D) orcid.org/0000-0003-0689-0705

Instytut Psychologii, Uniwersytet Jagielloński, Kraków Institute of Psychology, Jagiellonian University e-mail: martyna.jackiewicz@doctoral.uj.edu.pl

MARTA BIAŁECKA-PIKUL (D) orcid.org/0000-0002-0909-7123

Instytut Psychologii, Uniwersytet Jagielloński, Kraków Institute of Psychology, Jagiellonian University e-mail: marta.bialecka-pikul@uj.edu.pl

\title{
Kompetencja rodzicielska. Użyteczny konstrukt w badaniach nad rolą rodzicielskich oddziaływań w rozwoju dziecka ${ }^{1}$
}

\author{
Parenting Competence. A Useful Construct in Research \\ on the Role of Parental Influences in Child Development
}

\begin{abstract}
The aim of the considerations is to present the usefulness of the construct of "parenting competence" according to the understanding of Teti and Huang (2004) in research on the role of parenting influence in child development. Through a critical analysis of definitions of such concepts as "parental attitude" or "parenting style," the construct of parenting competence (PC) will be shown as allowing for a more precise, and at the same time, coherent and comprehensive characteristics of the most important components of parenting. PC will be presented as a construct which contains three important elements of parenting, namely: parental warmth, control and quality of communication. By presenting the potential usefulness of this construct, we will show that PC can be treated as a kind of social competence possessed by the parent. PC makes it possible to analyze parenting in the context of parent-child interaction, and at the same time takes into account the variability of parenting, which is culturally conditioned and, in this context, is strongly related to the developmental period, i.e., the child's age.
\end{abstract}

Keywords: parenting competence, parenting, parenting styles, parental attitudes.

Słowa kluczowe: kompetencja rodzicielska, oddziaływania rodzicielskie, style wychowania, postawy rodzicielskie.

\section{WPROWADZENIE}

W naukach społecznych, przede wszystkim socjologii, pedagogice i psychologii, funkcjonują dwa terminy odnoszące się do pełnienia społecznej roli rodzica: rodzicielstwo (parenthood) oraz oddziaływania rodzicielskie (parenting) (Galinsky, 1987; Hoghughi, 2004). Zajmując się za- gadnieniem rodzicielstwa, można współcześnie zadawać pytanie o to, jak w nowych rodzajach rodzin (np. w rodzinach, w których na świat przychodzi dziecko z zapłodnienia in vitro) zmienia się sposób spostrzegania przez rodziców swojej roli (zob. Golombok, 2015). Z kolei odnosząc się do oddziaływań rodzicielskich, psychologowie rozwoju nadal poruszają kwestie bardzo podsta- 
wowe, pytając mianowicie o rolę oddziaływań rodziców w rozwoju dziecka (zob. Morris, Cui, Steinberg, 2013). Wówczas w obszarze ich zainteresowań znajdują się zagadnienia dotyczące rodzicielskich praktyk, opisywane jednak za pomocą różnorodnej terminologii. Psychologowie rozwoju używają takich konstruktów, jak: ,postawa rodzicielska” (np. Plopa, 2011), ,styl wychowania” (np. Liberska, Matuszewska, 2004), „styl rodzicielski” (np. Darling, Steinberg, 1993) czy „styl dyscyplinowania” (np. Hart, DeWolf, Wozniak, Burts, 1992). Celem prezentowanych tu rozważań jest krytyczna analiza terminologii stosowanej dotychczas przede wszystkim w polskiej psychologii rozwoju oraz przedstawienie propozycji Douglasa Tetiego i Keng-Yen Huang (2004), aby oddziaływania rodziców opisywać w kategoriach kompetencji rodzicielskiej (KR). Posiadanie KR oznacza zdaniem autorów wchodzenie $\mathrm{z}$ dzieckiem w interakcje w sposób optymalny ze względu na jego wiek i dostarczanie mu oddziaływań, które będą sprzyjały osiąganiu przez nie rozwojowych rezultatów cenionych w danej kulturze. Ta operacyjna definicja KR zawiera trzy ważne elementy, które pozwalają krytycznie odnieść się do ujmowania rodzicielskich oddziaływań w kontekście postaw lub stylów wychowania. Po pierwsze, podkreśla ona rolę wzajemności w interakcji rodzic-dziecko; po drugie, zwraca uwagę na znaczenie dziecka i związanych z jego wiekiem właściwości dla oddziaływań rodzica; po trzecie, umieszcza zagadnienie rodzicielskich zachowań w kontekście kulturowym. Wykażemy, że wszystkie te trzy składniki są cenne dla uchwycenia kompletnej charakterystyki oddziaływań rodzicielskich, a zarazem nie w pełni uwzględniane w konstruktach postawy lub stylu. Na zakończenie naszych rozważań pokażemy również, dlaczego KR warto rozpatrywać jako szczególny rodzaj kompetencji społecznej (zob. Matczak, 2007).

\section{POSTAWY RODZICIELSKIE}

W polskiej psychologii obecna jest silnie zakorzeniona tradycja ujmowania oddziaływań rodziców w kategoriach postaw rodzicielskich (Plopa, 2011; Rembowski, 1972; Ziemska, 1973).
Maria Ziemska (1973) zdefiniowała postawę rodzicielską jako trójskładnikową, nabytą strukturę poznawczo-dążeniowo-afektywną, ukierunkowującą zachowanie się rodziców wobec dziecka. Poznawczy składnik postawy wyrażony jest w postaci poglądu na dziecko i może zawierać w sobie także ocenę jego zachowania, składnik afektywny znajduje odzwierciedlenie na przykład w tonie i sposobie wypowiedzi rodzica o dziecku, a przejawów składnika działania można upatrywać w sposobie traktowania dziecka i w stosowanym systemie nagród i kar. Za najważniejszy składnik autorka uważa komponent uczuciowy postawy, ponieważ to on odróżnia postawę od opinii oraz wyznacza działanie w stosunku do dziecka. Postawy rodzicielskie są również nazywane postawami wychowawczymi (Tyszkowa, 1985), ponieważ odnoszą się do oddziaływań rodziców na dziecko, mających charakter wychowawczy. Ponieważ w literaturze przedmiotu występuje jednak przede wszystkim termin ,postawa rodzicielska", to nim będziemy się konsekwentnie posługiwać $\mathrm{w}$ dalszych częściach artykułu.

Kontynuując myśl swoich polskich poprzedników z lat 70., Mieczysław Plopa podkreśla, że najczęściej powtarzające się wymiary postaw, uwzględniane przez różnych autorów, to: ciepło, wymagania oraz autonomia ${ }^{2}$. Autor ten uznaje za składniki postawy rodzicielskiej: sposób myślenia o dziecku, odczuwanie związanych z nim emocji oraz działanie, poprzez które rodzic wyraża poprzednie dwa elementy (Plopa, 2011) i proponuje zarówno własną typologię postaw (Plopa, 1987, 2008), jak i narzędzia pomiarowe, które pozwalają zmierzyć postawy rodziców wobec swoich dzieci oraz - co naszym zdaniem najważniejsze - postawy przejawiane przez rodziców, tak jak postrzegają je dzieci i młodzież $\dot{z}^{3}$ Innymi słowy, Plopa (2011) dostrzegł, że dla opisania rodzicielskiej postawy istotne jest również to, jak dziecko odbiera, czyli interpretuje rodzicielskie oddziaływania i reaguje na nie (Grusec, Goodnow, 1994). Jest to pierwszy krok do dostrzegania, że dziecko jest aktywnym podmiotem oddziałującym zwrotnie na rodzica (tzw. efekt dziecka, child's effect Grusec, 2011; Parke, Buriel, 2006). O tym, jakie znaczenie zostanie ostatecznie przypisane oddziaływaniom rodzica na dziecko, nie decy- 
duje ich inicjator, ale właśnie dokonujący ich interpretacji odbiorca (Leadbeater, Raver, 1995; Peterson, Peters, 1983). To właśnie odbierane przez dziecko, wynikające z postaw, działania rodzica mają na jego rozwój relatywnie większy wpływ niż przekonania, które deklarują rodzice (np. Brzozowski, 1988; Kowalski, 1982).

Istotną cechą postawy rodzicielskiej jest zdaniem wielu autorów plastyczność, czyli jej zmienność z upływem czasu (np. Ziemska, 1973). Zmiany postawy uwarunkowane są fazą rozwojową, w jakiej aktualnie znajduje się dziecko. Tym, co podlega zmianie, jest stopień i jakość swobody, jaką dziecko otrzymuje od rodziców, oraz jakość form kontrolowania dziecka, zgodna z jego wiekiem (Ryś, 1994; Ziemska, 1986). Choć autorzy piszą o zmienności postaw rodzicielskich ze względu na wiek dziecka, i tu szczególnie o zmianach zachodzących w wymiarze rodzicielskiej kontroli, to jednak ich postulaty nie znajdują niestety odzwierciedlenia na poziomie pomiaru postaw. Przede wszystkim nie są obecnie dostępne narzędzia do oceny postaw rodzicielskich, które byłyby przeznaczone dla rodziców dzieci w określonym wieku, na przykład dzieci w okresie wczesnego dzieciństwa. Polscy badacze najczęściej mierzą postawy rodzicielskie w percepcji młodzieży, a stosowana w tych badaniach instrukcja wymaga oceny postępowania rodziców wobec badanych do ukończenia przez nich 12. roku życia (np. Olszewski, Talik, Oleś, 2016). Jest to zatem badanie retrospektywne, wrażliwe na zniekształcenia pamięciowe oraz wpływ aktualnej relacji rodzic-dziecko na ocenę tej relacji w przeszłości. Co istotne, badany musi odwołać się do szerokiego zakresu wieku, w którym rodzice mogli zmieniać i prawdopodobnie zmieniali swoje postawy wobec niego. Z kolei gdy badacze stosują skale samoopisowe dla rodziców, zdarza się, że badają rodziców dorosłych już dzieci (np. Suwalska-Barancewicz, Malina, 2013). Nie można zatem, stosując dostępne w Polsce narzędzia, dokonać pomiaru postaw rodzicielskich, który uwzględni wiek badanych dzieci i zmiany w postawach rodziców ze względu na ten wiek.

Innym zarzutem, jaki można sformułować wobec badań prowadzonych z użyciem kwestionariuszy do pomiaru postaw, jest dostrzeżenie słabości narzędzi samoopisowych. Jeśli przyjąć, że postawę wobec jakiegoś obiektu (w tym osoby) definiuje się dziś jako względnie trwałą tendencję do pozytywnego lub negatywnego traktowania tego obiektu (por. Wojciszke, 2011), to wyraża się ona zarówno w jawnej, deklarowanej w kwestionariuszu ,gotowości do działania”, jak i w niejawnym czy niepoddanym świadomej refleksji ustosunkowaniu, które można mierzyć za pomocą obserwacji, na przykład reakcji niewerbalnych. Te dwa rodzaje postaw - jawne i niejawne - nie muszą być (i często nie są) z sobą zgodne (np. Maliszewski, Czyżewska, Krejtz, 2009). Biorąc pod uwagę, że kwestie dotyczące sposobu wychowywania dzieci z pewnością są podatne na wpływ czynnika aprobaty społecznej, badanie przez psychologów rozwojowych wyłącznie deklarowanych postaw rodzicielskich nie pozwala na uzyskanie pełnego obrazu oddziaływań rodzicielskich. Jak piszą Nancy Darling i Laurence Steinberg (1993), choć rodzicielskie postawy determinują zachowania rodziców wobec dziecka, to jednak swój wyraz postawa znajduje zawsze i przede wszystkim w zachowaniu. W związku z tym, zdaniem autorów, nieuzasadnione jest badanie tylko postaw jako deklaracji, bez równoczesnej analizy zachowań.

Podsumowując, konstrukt postawy rodzicielskiej - przynajmniej tak jak jest on obecnie często badany przez polskich psychologów rozwoju - ma niestety ważne ograniczenia. Po pierwsze, nie uwzględnia się w badaniach postaw niejawnych, niedeklaratywnych, a wyrażających się w rzeczywistym zachowaniu rodzica lub podejmowanych przez niego decyzjach podczas konkretnych, naturalnych sytuacji. Po drugie, operacjonalizacja postaw rodzicielskich nie odnosi się do kwestii wieku czy, szerzej: fazy rozwoju dziecka, co - jak zauważają twórcy tego konstruktu - powinno być uwzględniane w pomiarze postaw. Po trzecie, i chyba najważniejsze, uznając, że postawa jest ustosunkowaniem się podmiotu, którym jest rodzic, do/wobec przedmiotu, czyli dziecka, już z definicji postawy zakłada się jednokierunkowość oddziaływań: od rodziców do dziecka. W ten sposób pomija się ważne odkrycia psychologii rozwoju opisane jako tak zwany efekt dziecka (np. Ambert, 1992). Zależność oddziaływań rodziców od za- 
chowań dziecka ukazano na przykład w obszarze badań nad temperamentem (Coplan, Reichel, Rowan, 2009) czy mediami i komunikacją (Van den Bulck, Van den Bergh, 2005), co pozostaje zgodne z tezą transakcyjnych modeli rozwoju (zob. Sameroff, 2009). Oddziaływania rodzicdziecko są nie tylko obustronne (bi-directoral), ale i wzajemne (transactional) - w procesie rozwoju partnerzy interakcji wzajemnie i ciągle oddziałują na siebie. Relacja rodzic-dziecko stanowi jedynie podsystem w mikrosystemie rodziny, w ramach szeroko rozumianego systemu kultury danego społeczeństwa (Bronfenbrenner, 1979). W tym kontekście wydaje się, że w badaniach nad oddziaływaniami rodzicielskimi należałoby poszukiwać takiego konstruktu, który w większym stopniu uwzględni kwestie niejednokierunkowości i zmienności oddziaływań rodziców wynikających z wieku dziecka oraz - co ukażemy poniżej - zakorzenionych w kulturze sposobów odnoszenia się rodziców do dziecka.

\section{STYLE WYCHOWANIA}

Drugim najczęściej stosowanym na gruncie polskim konstruktem w obszarze teorii i badań nad oddziaływaniami rodzicielskimi jest „styl wychowania". Definiuje się go jako wypadkową sposobów i metod oddziaływania na dziecko przez wszystkich członków rodziny, w tym rodziców (Kuczkowski, 1991), dobór oraz zastosowanie w praktyce zestawu określonych środków wychowawczych (Ziemska, 1973). Uwzględniając wymiar ciepła w relacji rodzic-dziecko, ale szczególnie akcentując wymiar stawianych dziecku wymagań, za najczęściej wyróżniane w rodzimej literaturze przedmiotu style wychowania należy uznać: demokratyczny, autokratyczny i liberalny (Bakiera, 2018; Ryś, 2009). Za ogólnie najbardziej korzystny dla rozwoju dziecka uznaje się styl demokratyczny, którego istotą jest aktywny udział dziecka w relacji z rodzicami przy jednoczesnym wysokim poziomie stawianych mu wymagań. Rodzicielska kontrola opiera się przy tym na perswazji, wyjaśnianiu i odbywa się w kontekście ciepłego klimatu emocjonalnego. Styl autokratyczny cechuje emocjonalny dystans w relacji rodzic-dziecko, a wymogi stawiane dziecku są wysokie, często zbyt wysokie w stosunku do jego możliwości. Ich egzekwowanie ma zazwyczaj represyjny charakter. Charakterystyczne dla stylu liberalnego jest całkowite podporządkowanie się dziecku przez rodziców, okazywanie mu ciepłych uczuć przy jednoczesnych deficytach w zakresie rodzicielskiej kontroli (Liberska, Matuszewska, 2014). Ponadto niektórzy autorzy wyróżniają również styl niekonsekwentny, w ramach którego oddziaływania rodzicielskie cechują zmienność i niesystematyczność, zależność od aktualnego samopoczucia rodzica i czynników zewnętrznych (Borecka-Biernat, 1995; Przetacznik-Gierowska, Włodarski, 1998).

W literaturze światowej częściej niż z pojęciem „styl wychowania” można spotkać się z określeniem ,styl rodzicielski” (parenting style). Polscy autorzy, przywołując zagraniczne konceptualizacje stylów rodzicielskich, nazywają je „stylami wychowania” (np. Cierpka, Wierzbicka, 2013) bądź traktują te dwa terminy wymiennie (np. Liberska, Matuszewska, 2014). Wynika to być może $\mathrm{z}$ tego, że analizując opisy poszczególnych stylów wychowania i rodzicielskich, można dojść do wniosku, iż demokratyczny styl wychowania jest właściwie tożsamy $\mathrm{z}$ autorytatywnym stylem rodzicielskim, styl autokratyczny - ze stylem autorytarnym, a liberalny z permisywnym (por. Baumrind, 1968, 1980, 1993). Podobieństwa można również dostrzec w zakresie uwarunkowań i komponentów stylów wychowania i stylów rodzicielskich. Nancy Darling i Laurence Steinberg (1993), zestawiając różne konceptualizacje stylów rodzicielskich, podkreślają, że składają się one z elementu istotnych z punktu widzenia rodzica: wartości oraz celów przyświecających rodzicom w procesie wychowywania dziecka, z praktyk rodzicielskich, które prowadzą do urzeczywistniania tych wartości i celów oraz z postaw rodziców wobec dzieci. O stylach wychowania decydują między innymi poglądy rodziców odnośnie do sposobów oddziaływania na dziecko i cele wychowawcze, które zamierzają oni osiągnąć, a w danym stylu przejawiają się postawy rodzicielskie (Liberska, Matuszewska, 2014). Z kolei konkretne środki wychowawcze wybierane i stosowane w ramach stylu wychowania wydają się po prostu zbiorem 
rodzicielskich praktyk. Biorąc zatem pod uwagę podobieństwo treściowe obu terminów, a także istniejącą w polskiej literaturze tradycję posługiwania się określeniem ,styl wychowania”, w dalszej części artykułu częściej będziemy używać terminu ,styl wychowania”, a jedynie gdy w oryginalnym piśmiennictwie anglojęzycznym konstrukt występował pod nazwą ,stylu rodzicielskiego", pozostaniemy przy oryginalnej nazwie.

Twórczyni prawdopodobnie najbardziej znanej w światowej literaturze typologii stylów rodzicielskich, Diane Baumrind (1971), jak również kontynuatorzy jej podejścia (np. Darling, Steinberg, 1993), twierdzą, że styl ten jest charakterystyką rodzica, a nie relacji rodzic-dziecko. Podobnie w polskiej literaturze przedmiotu pojawia się rozumienie stylu wychowania w kategoriach naturalnych oddziaływań rodzica nakierowanych na dziecko, wpływających na jego zachowanie (por. Liberska, 2007). Zatem, podobnie jak w przypadku postaw, w konceptualizacjach stylu funkcjonuje założenie o jednokierunkowości wpływów - to rodzice oddziałują na dziecko.

Darling i Steinberg (1993) w swoim autorskim modelu oddziaływań rodzicielskich traktują styl rodzicielski jako cechę rodzica, niezależną od charakterystyk rozwijającego się dziecka, i odróżniają go od rodzicielskich praktyk. Styl rodzicielski jest, zdaniem tych autorów, wytwarzanym przez rodzica pewnym emocjonalnym klimatem, w ramach którego realizuje on rodzicielskie praktyki, czyli działania podporządkowane celom socjalizacyjnym, które chce on osiągnąć. O ile styl rodzicielski zachowuje stałość z upływem czasu, o tyle rodzicielskie praktyki przyjmują różną postać, relatywnie do fazy rozwojowej, w jakiej znajduje się dziecko. $\mathrm{W}$ takim rozumieniu styl pełni funkcję moderatora zależności pomiędzy rodzicielskimi praktykami a rezultatami rozwojowymi widocznymi u dziecka (Fletcher, Walls, Cook, Madison, Bridges, 2008). Wydaje się jednak, że rozdzielanie emocjonalnego klimatu oddziaływań, który wynika z cech rodzica, od praktyk rodzicielskich, które są efektem cech rozwojowych dziec$\mathrm{ka}$, jest konceptualizacją trudną w realizacji oraz znajdującą słabe wsparcie koncepcyjne, gdy uwzględnimy tezę, że rozwój jest procesem transakcyjnym (Sameroff, 2009).
Odniesienia do uwzględniającego wiek dziecka stylu wychowania, traktowanego jako połączenie ustosunkowania się rodziców wobec dziecka ze stosowanymi przez nich metodami wychowania, pojawiają się także w polskiej literaturze pedagogicznej (Obuchowska, 2009; Pluta, 1979). W niektórych pracach (np. Ostafińska-Molik, Wysocka, 2014) podkreśla się rozwojowe znaczenie stylów wychowania, rozpatrywane w kategoriach ich dopasowania do potrzeb rozwojowych dziecka, związanych z jego aktualnym wiekiem. Autorki podają przykład takiego rozwojowego dopasowania, odwołując się do komponentu sprawowania kontrolidla małego dziecka najbardziej korzystny będzie autokratyczny styl jego rodziców, podczas gdy do adolescenta, potrzebującego więcej wolności i swobody, bardziej dopasowany będzie styl demokratyczny oraz liberalny kochający. Pamiętając jednak o tym, że oddziaływania rodziców związane $\mathrm{z}$ wymiarem emocjonalnym i ze sprawowaniem kontroli trudno rozdzielić oraz biorąc pod uwagę, że ilość kontroli zależy również od cech temperamentu dziecka (np. Putnam, Sanson, Rothbart, 2002), takie podejście należy uznać za nadmierne uogólnienie.

Ciekawą koncepcję łączącą różne poziomy oddziaływań w relacji rodzic-dziecko proponuje współcześnie Lucyna Bakiera (2013, 2017, 2018). Autorka stworzyła typologię stylów realizowania rodzicielstwa, nazywanych też stylami rodzicielskimi. Zaproponowana konceptualizacja podkreśla znaczenie nie tylko cech osobowych rodzica (jak np. stopień identyfikacji z rolą matki/ojca), dziecka (np. uwarunkowania osobowościowe), ale też charakterystyk interakcji rodzic-dziecko (np. ich częstość i jakość) oraz kontekstowych (np. na poziomie egzosystemu dostępność instytucji wychowawczych, takich jak przedszkola czy żłobki). Styl realizowania rodzicielstwa ujmowany jest przy tym nie jako prosty zbiór tych cech, ale jako system, który charakteryzuje dynamizm i wzajemne wpływanie na siebie jego poszczególnych elementów (Bakiera, 2017, 2018). Uwzględnianie tak szerokiej grupy czynników wpływających na rodzicielstwo pozostaje w zgodzie z przyjętym współcześnie w rozważaniach o relacji rodzic-dziecko podej- 
ściem ekologicznym (Bronfenbrenner, 1993). Wyróżnione przez autorkę style realizowania rodzicielstwa: zaangażowany, wycofany oraz awersyjny korespondują przy tym z postawami rodzicielskimi i stylami wychowania określanymi jako pozytywne (dla stylu zaangażowanego) i negatywne (dla stylów wycofanego i awersyjnego). Propozycja autorki jest niewątpliwie cenna, gdyż dzięki uwzględnieniu tak szerokiej gamy czynników zdecydowanie wykracza poza uproszczone rozumienie relacji rodzic-dziecko w kategorii jednokierunkowych oddziaływań, zwracając uwagę nie tylko na znaczenie często pomijanej drugiej strony tej relacji, jaką jest dziecko, ale również na istotność czynników istniejących w szerszych systemach, niejako poza tą relacją, mogących jednak wpływać na to, jak rodzic realizuje swoją rolę. Wydaje się, że tak szeroki sposób rozumienia zbliżony jest jednak treściowo do najbardziej ogólnego terminu odwołującego się do ogółu czynników związanych z ,koncepcją roli” rodzica, czyli angielskiego parenting, wykraczającego z kolei poza elementy tradycyjnie ujmowane w ramach stylów rodzicielskich (parenting styles).

Dokonując analizy pojęcia stylu wychowania i stylu rodzicielskiego, można stwierdzić, że w opozycji do pojęcia postawy - najważniejszy składnik stylu to jednak nie tyle komponent emocjonalny, ile wyrażający się w sposobach sprawowania kontroli komponent działaniowy, czyli praktyki wychowawcze, a szczególnie skuteczność tych praktyk mierzona poprzez wychowawcze skutki, do jakich one doprowadzają. Badacze zasadniczo poszukiwali opisu stylów wychowania właśnie po to, by określać skutki wychowawcze, zwłaszcza te odnoszące się do społecznych zachowań dziecka i jego osobowości (zob. omówienie: Parke, Clark-Stewart, 2011). Jak krytycznie zauważa Katarzyna Martowska (2012), wydaje się, że autorzy badań nad stylami wychowania większą wagę przywiązują właśnie do skutków stosowania danego stylu niż do opisu zachowań, które się na dany styl składają, co jednak nie oznacza, że nie są dostępne narzędzia służące do pomiaru stylów.

W literaturze zagranicznej znajdziemy wiele narzędzi służących do pomiaru stylów rodzicielskich, w tym również tak zwanych stylów dyscyplinowania, które odnoszą się wtedy tylko do sytuacji, gdy rodzic sprawuje kontrolę nad zachowaniem dziecka i stawia dziecku wymagania (np. Hart, Ladd, Burleson, 1990), przy czym, podobnie jak w przypadku postaw rodzicielskich, są to metody samoopisowe. Również polscy autorzy do badania stylów wychowania używają kwestionariuszy ${ }^{4}$. Podsumowując, można zatem twierdzić, że również pojęcie stylu wychowania obciążone jest wcześniej wskazanymi ograniczeniami, które cechują postawy: skupia się na jednokierunkowości oddziaływań rodzica na dziecko, zwłaszcza na wymiarze kontroli zachowań dziecka, a na poziomie pomiaru nie uwzględnia wieku dziecka oraz kulturowych uwarunkowań praktyk rodzicielskich.

W naszej opinii użycie nowego terminu, a mianowicie pojęcia ,kompetencji rodzicielskiej”, mogłoby sprzyjać doprecyzowaniu istoty oddziaływań rodzicielskich oraz stworzeniu nowych narzędzi pomiarowych. Dlatego teraz należy ukazać konstrukt KR, uwzględniając najważniejsze koncepcje wyjaśniające istotę rodzicielskich oddziaływań.

\section{ODDZIALYWANIA RODZICIELSKIE. TLO TEORETYCZNE}

Należy przyjąć, że oddziaływania rodziców na dziecko są tylko jednym z elementów relacji rodzic-dziecko. Wspomniany już powyżej tak zwany efekt dziecka należy uwzględniać w każdym badaniu oddziaływań rodzicielskich, ponieważ zawsze można twierdzić, że dane zachowanie rodzica przynajmniej częściowo jest uwarunkowane zachowaniem dziecka. W polskiej literaturze z zakresu psychologii rozwoju Elżbieta Dryll (1995) przedstawia takie interakcyjne podejście. Autorka zaleca dystansowanie się od potocznej definicji procesu wychowawczego jako działalności jednostki (najczęściej osoby dorosłej) skierowanej na kształtowanie innej jednostki (zwykle dziecka), proponując jego rozumienie w kategoriach dwupodmiotowej interakcji: sytuacji, w której oba te podmioty wzajemnie na siebie działają oraz współtworzą zdarzenia. Autorka podkreśla dynamikę procesu interakcyjnego, definiując go jako strumień 
wspólnej aktywności. Z tak zarysowanej perspektywy w diadzie rodzic-dziecko to dwaj uczestnicy pełnią określone funkcje. Nie są one równorzędne, ponieważ to na osobie dorosłej spoczywa pełna, społeczna odpowiedzialność za to, co się w tej relacji dzieje, ale równocześnie, jako że są one zarazem komplementarne, interakcja nie jest też całkowicie od dziecka niezależna. To właśnie dynamiczny, interakcyjny charakter relacji rodzic-dziecko sprawia, że lepszym od metod samoopisowych, takich jak kwestionariusze, sposobem jej badania jest obserwacja. To właśnie obserwacja w sposób bezpośredni i zobiektywizowany pozwala ocenić zachowania rodzica $w$ różnych wymiarach. W kwestionariuszach wypełnianych przez rodzica czy dziecko dokonywana ocena ma charakter pośredni i subiektywny (Stemplewska-Żakowicz, 2008).

Obserwacja w środowisku naturalnym i w sytuacji laboratoryjnej to narzędzia stosowane $w$ badaniu interakcji rodzica $\mathrm{z}$ dzieckiem w każdym wieku. W tradycji wyrastającej z teorii przywiązania (Ainsworth, Blehar, Waters, Wall, 1978) obserwacja pozwala na badanie rodzicielskiej wrażliwości (parental sensitivity) czy innych form responsywności (responsivity, zob. Bornstein, Tamis-LeMonda, Hahn, Haynes, 2008), która sprzyja rozwojowi dziecka. Badając responsywność, odnoszono się przede wszystkim do reakcji rodzica, które Joan Grusec i Maayan Davidov $(2010,2015)$ określają jako socjalizację w obszarze ochrony i wzajemności. Autorzy ci opisali pięć obszarów socjalizacji (ochrona, wzajemność, kontrola, nauczanie, udział w społeczności), z których dwa pierwsze wydają się silnie powiązane $z$ afektywnym aspektem praktyk rodzicielskich, a trzy pozostałe - z wymiarem dyscyplinowania i autonomii, który można odnosić do rodzicielskiej kontroli. Warto podkreślić, że afektywny aspekt rodzicielskich oddziaływań częściej badany był w tradycji przywiązaniowej w odniesieniu do relacji rodzica z małym dzieckiem (np. Barnard, 1994), natomiast elementy kontroli, nauczania i sposobów uczestniczenia w sytuacjach społecznych to te aspekty praktyk rodzicielskich, które stanowią ważne wyzwanie dla rodziców dzieci starszych w wieku poniemowlęcym, przedszkolnym, a nawet szkolnym (zob. przegląd badań: Gauvain,
Perez, Beebe, 2013). Można więc twierdzić, że takie ujęcie unaocznia istotne znaczenie, jakiego wraz z wiekiem dziecka nabierają inne niż wrażliwość i ciepło elementy oddziaływań rodzicielskich. Na przykład pod koniec okresu przedszkolnego, kiedy to rosną wymagania dotyczące samokontroli i uczenia się, rodzice skłaniają się do silniejszego ukierunkowania swoich praktyk na kontrolę i dyscyplinę. Myśl tę prezentują również Douglas Teti i Keng-Yen Huang (2004), autorzy koncepcji kompetencji rodzicielskiej, która zostanie przedstawiona w kolejnej części artykułu. Zarysowując jednak jej tło teoretyczne, należy dostrzec jeszcze jeden ważny aspekt oddziaływań rodzicielskich, a mianowicie kwestię zanurzenia tych oddziaływań w kulturze.

Urie Bronfenbrenner (1979, 1993), autor teorii systemów ekologicznych, jako pierwszy zwrócił uwagę na to, że oddziaływania rodziców na dziecko nie odbywają się w próżni, a wręcz przeciwnie - pozostają pod wpływem innych systemów, w których bezpośrednio lub pośrednio uczestniczy dziecko i które wzajemnie na siebie oddziałują. Jeśli oddziaływania rodzicielskie są elementem mikrosystemu, to tenże funkcjonuje w ramach mezo-, egzo-i makrosystemu. W szczególności makrosystem, czyli system tradycji, kultury, ideologii, może kształtować przekonania rodziców dotyczące wychowania i roli rodzica, które wpływają na ich zachowania. Z kolei Charles Super i Sara Harkness (1986), autorzy koncepcji niszy rozwojowej, twierdzą, że posiadane przez rodziców etnoteorie, czyli przekonania dotyczące natury rozwoju dziecka i jego potrzeb oraz efektywnych strategii wychowawczych, określają cele socjalizacyjne, jakie rodzice chcą realizować w procesie wychowywania. Cele te opisują zatem rozwojowe rezultaty, do jakich dążą rodzice poprzez swoje rodzicielskie praktyki. Odwołując się jedynie do tych dwóch klasycznych koncepcji, można twierdzić, że błędem jest traktowanie relacji rodzic-dziecko jako niezależnej od szerszego, kulturowego kontekstu. Przedstawione powyżej konceptualizacje postaw i stylów rodzicielskich niemalże pomijają fakt, że oczekiwane przez rodziców rozwojowe rezultaty są wyznaczane przez kulturę, w której dana rodzina funkcjo- 
nuje. Na przykład to, czy rodzic wysoko ceni samokontrolę i kompetencje poznawcze, zależy przynajmniej po części od tego, czy takie kompetencje uznawane są za cenne w jego społeczności, a więc będzie prawdopodobnie skłonny ukierunkować swoje oddziaływania na kształtowanie takich umiejętności u dziecka, zwłaszcza gdy dziecko zacznie zbliżać się do okresu formalnej edukacji szkolnej.

\section{KOMPETENCJA RODZICIELSKA}

Pierwsze próby konceptualizacji pojęcia ,kompetencji rodzicielskiej” podjęto w latach 80 . XX wieku. Jay Belsky, Elliot Robins i Wendy Gamble (1984), chcąc odżegnać się od toczącej się w tamtym czasie gorącej dyskusji na temat tego, co oznacza ,dobre”, a co ,złe” rodzicielstwo, odwoływali się do zaczerpniętego z biologii ewolucyjnej pojęcia adaptacji. Autorzy ci opisują tak zwane kompetentne rodzicielstwo jako taki styl wychowywania dziecka, który w rezultacie pozwala mu na nabycie zdolności do efektywnego radzenia sobie w obrębie nisz ekologicznych, jakie będzie ono zamieszkiwać. Belsky i współpracownicy (1984) podkreślali relatywny charakter tego konstruktu, wyraźnie zaznaczając, że ich ustalenia odnoszą się wyłącznie do osób klasy średniej społeczności Stanów Zjednoczonych. Przyjmując systemowe rozumienie rodziny, podali oni trzy źródła kompetentnego rodzicielstwa. Są to: 1) osobiste zasoby rodzica; 2) charakterystyki dziecka oraz 3) społeczne źródła stresu i wsparcia. Autorzy podkreślają dwukierunkowość wpływów w relacji rodzic-dziecko oraz twierdzą, że rodzicielstwo kompetentne oznacza: 1) wrażliwe dostrojenie się do możliwości dziecka oraz do zadań rozwojowych, którym musi ono sprostać; 2) osiąganie ważnych rezultatów rozwojowych (np. dziecko staje się kompetentne społecznie). W okresie niemowlęcym kompetentne rodzicielstwo manifestuje się we wrażliwym reagowaniu na sygnały wysyłane przez dziecko. W późniejszych okresach rozwoju wrażliwość w dalszym ciągu oznacza dostarczanie rodzicielskiego ciepła, jednak przy jednoczesnym zwiększaniu nacisku na kontrolowanie zachowania dziecka tak, by było ono adekwatne do jego wieku. Podsumowując, choć Belsky i współpracownicy (1984) opisali kompetentne rodzicielstwo, które zmienia się z wiekiem dziecka, wydaje się, że jedynie zastąpili nim pojęcie „dobrego" rodzicielstwa, ale nie zdefiniowali oddziaływań rodzicielskich w kategoriach umiejętności, czyli kompetencji samego rodzica. Takie wyzwanie postawili sobie Douglas Teti i Keng-Yen Huang (2004), autorzy piszący o „rodzicielskiej kompetencji”.

Już na wstępie swojego tekstu poświęconego kompetencji rodzicielskiej Teti i Huang (2004) piszą o trudnościach, jakie wiążą się ze sformułowaniem definicji tego konstruktu. Spowodowane są one, zdaniem autorów, koniecznością rozpatrywania oddziaływań składających się na KR zawsze w kategoriach skutków, jakie za sobą niosą dla rozwoju dziecka. Innymi słowy, Teti i Huang prezentują podejście, zgodnie z którym „kompetencja rodzicielska może być definiowana wyłącznie w kategoriach skłonności (propensity), z jaką przybliża ona dziecko do osiągania rezultatów rozwojowych uważanych za istotne w danej kulturze" (Teti, Huang, 2004, s. 161). Nie sposób jest więc stworzyć jednej definicji kompetencji rodzicielskiej, ponieważ, zgodnie z istniejącymi danymi empirycznymi, dla różnych rezultatów rozwojowych odmienne rodzicielskie oddziaływania można uznać za optymalne, a same te rezultaty wynikają z kolei z wymagań nakładanych przez system kultury, w którym wychowuje się dane dziecko. Można więc powiedzieć, że KR w odniesieniu na przykład do niezależności, czyli charakterystyki cenionej w zachodniej kulturze, będzie zawierała w sobie inne elementy niż KR w odniesieniu do wykształcenia u dziecka posłuszeństwa, które to stanowi istotny cel rozwojowy w wielu społeczeństwach spoza zachodniego kręgu kulturowego (Baumrind, 1971; Super, Harkness, 1986). Również te same elementy KR mogą mieć różne znaczenie w zależności od kultury, ponieważ o różnicach stanowić będzie cel rozwojowy, do którego dąży rodzic. Posługiwanie się surowymi środkami dyscyplinowania przez afroamerykańskie matki prowadzi do pożądanego rezultatu, jakim jest niska skłonność nastolatków do angażowania się w działalność przestępczą. Takie środki, charakterystyczne dla autorytar- 
nego stylu wychowania w zachodniej kulturze, wiążą się z kolei z celem bezwzględnego podporządkowania sobie dziecka (Walker-Barnes, Mason, 2001). Ponadto kultury różnią się tym, co w ich ramach uznawane jest za „właściwe” czy „pożądane” u dziecka w konkretnej fazie rozwoju, czyli oczekiwaniem, jakie cele rozwojowe w jakim wieku ,powinny” być przez dziecko osiągnięte. W związku z tym składniki KR zmieniają się wraz z wiekiem dziecka, gdyż na każdym etapie jego rozwoju kultura wyznacza inne rozwojowe rezultaty, do których dążą rodzice w procesie wychowywania. Co istotne, Teti i Huang (2004), podobnie jak wcześniej Belsky i współpracownicy (1984), wyraźnie zaznaczają, że ich ustalenia odnośnie do składników KR ograniczają się do: 1) zachodniej kultury; 2) dwóch rezultatów rozwojowych cenionych w tej kulturze, którymi są kompetencje społeczne w odniesieniu do rówieśników i dorosłych oraz wykształcenie wzajemnej, interpersonalnej orientacji rodzic-dziecko (mutual interpersonal parent-child orientation). Jak wspomniano wyżej, składniki KR zmieniają się wraz z wiekiem dziecka. I tak, odnosząc się tylko do kultury zachodniej, Teti i Huang (2004) piszą, że KR wobec dziecka w okresie niemowlęcym uwidacznia się przede wszystkim we wrażliwości rodzica i rozpoznawaniu wysyłanych przez nie sygnałów oraz adekwatnym reagowaniu na nie. Teti i Huang (2004) odwołują się tu do konceptualizacji Mary Ainsworth (Ainsworth i in. 1978), postulując, że kompetencja rodzica w tym okresie rozwoju dziecka oznacza działania dążące do wytworzenia między nim a dzieckiem bezpiecznego wzorca przywiązania. Innymi słowy, są to zachowania utożsamiane z rodzicielską wrażliwością, która wyraża się w emocjonalnej responsywności. „Bycie wrażliwym” może się również odnosić do jakości rodzicielskich oddziaływań na przestrzeni dalszych okresów rozwojowych, ale wraz z wiekiem dziecka zmienia się zakres sytuacji, w których owa wrażliwość jest najwyraźniej dostrzegalna. Na przykład przejawy wrażliwości w odniesieniu do dziecka w okresie średniego dzieciństwa to rozpoznawanie i wrażliwe reagowanie przez opiekuna na dziecięce prośby o pomoc w sytuacjach zadaniowych, czyli tak zwana wspierająca obecność opiekuna (supportive presence) (Pianta, Sroufe, Egeland, 1989). Wkroczenie dziecka w okres poniemowlęcy, a później średniego dzieciństwa w kulturze zachodniej powoduje poszerzenie zakresu KR o dwa komponenty: znaczenia nabierają wyrażająca się w dyscyplinowaniu dziecka rodzicielska kontrola oraz jakość komunikacji z dzieckiem, na którą składają się komunikaty odnośnie do oczekiwanych zachowań dziecka. Najbardziej optymalnym z punktu widzenia przywoływanych przez autorów rezultatów rozwojowych sposobem dyscyplinowania dziecka jest przy tym odwoływanie się przez rodzica do wyjaśnień stosowanych przez niego działań, podawanie ich racjonalnych uzasadnień (reasoning(explanation, por. Hoffman, 1994). KR rozumiana jako kompetentne zachowanie się rodzica względem dziecka w średnim dzieciństwie jest zatem konstruktem trójelementowym, na który składają się: 1) rodzicielskie ciepło; 2) rodzicielska kontrola oraz 3) jakość komunikacji z dzieckiem. W trzecim z tych elementów wyrażają się dwa poprzednie, gdyż swoje odzwierciedlenie w kierowanych do dziecka komunikatach znajduje nie tylko komponent dyscyplinowania, ale również komponent emocjonalny, czyli rodzicielskie ciepło. Wydaje się zatem, że zarówno elementu dyscypliny, jak i składnika związanego z emocjonalnym klimatem relacji rodzic-dziecko nie sposób rozpatrywać w oderwaniu od komunikacji, która niejako przenika te dwa poprzednie wymiary. Komunikacja cechująca się wysoką jakością wyraża się przy tym zdaniem autorów w jasnym przekazywaniu dziecku wymagań odnośnie do właściwych sposobów postępowania przy jednoczesnym zachowaniu zasad responsywnego dialogu (responsive dialog), kiedy to rodzic w kierowanych do dziecka komunikatach uwzględnia jego uczucia, potrzeby i możliwości rozwojowe. Oczywiście komunikacja, jako składnik przenikający wszystkie międzyludzkie interakcje, w tym również interakcje rodzic-dziecko, nie pojawia się dopiero w czasie, gdy dziecko przechodzi do okresu średniego dzieciństwa. Interakcje twarzą w twarz czy protodialogi w diadzie rodzic-niemowlę stanowią przykłady wczesnych zachowań komunikacyj- 
nych (Stephens, Matthews, 2014). Powodem, dla którego Teti i Huang (2004) podkreślają istotność jakości komunikacji jako składnika KR w odniesieniu do dziecka akurat w okresie średniego dzieciństwa, jest potwierdzane w badaniach empirycznych założenie, że właśnie taki jak opisany powyżej rodzaj komunikacji stanowi przejaw adaptacji rodzica w odniesieniu do zmieniających się potrzeb dziecka oraz jego możliwości, zwłaszcza w obszarze komunikacji. Dzięki nastawionej na dialog komunikacji dwóch coraz bardziej równorzędnych partnerów możliwe staje się stworzenie wzajemnej interpersonalnej orientacji w diadzie rodzic-dziecko oraz u samego dziecka rozwijają się kompetencje społeczne konieczne do komunikowania się $\mathrm{z}$ innymi dorosłymi i z rówieśnikami.

Podsumowując, dodać należy, że w przytaczanych przez Tetiego i Huang (2004) badaniach dominującą metodą zbierania danych odnoszących się do składników KR wobec dzieci w różnych okresach rozwojowych jest obserwacja. Skupienie na pomiarze obserwowalnych w trakcie interakcji z dzieckiem zachowań rodzica pozwala ocenić, co rodzic rzeczywiście w tej interakcji robi, a nie tylko na to, co deklaruje, $\dot{z} e$ robi, gdy badamy jego oddziaływania z użyciem metod samoopisowych. Składniki ciepła i kontroli KR są względem siebie rozłączne i możliwe do pomiaru z użyciem osobnych miar. Jakość komunikacji nie ma jednak tak jasnego statusu i z pewnością trudniej ją jednoznacznie zoperacjonalizować. Autorzy koncepcji KR podkreślają, że jakość komunikacji jest cechą KR szczególnie istotną w okresie średniego dzieciństwa, gdyż w zachodniej kulturze pozwala ona na realizowanie dwóch ważnych celów socjalizacyjnych: wzajemnej interpersonalnej orientacji w diadzie rodzic-dziecko oraz rozwijania kompetencji społecznych dziecka. Jednocześnie autorzy składniki te traktują jako dymensje, co daje możliwość określania nasilenia każdego z nich oraz tworzenia na tej podstawie profilów opisujących oddziaływania rodziców. Teti i Huang dopuszczają więc możliwość istnienia takiego profilu oddziaływań rodziców wobec dziecka, który, uwzględniając cele socjalizacyjne wynikające $\mathrm{z}$ jego wieku, można uznać za przejaw rodzi- cielskiej niekompetencji. Na przykład wyrazem niekompetencji rodzica może być zbyt wysoki lub zbyt gwałtownie rosnący poziom kontroli zachowań dziecka w pierwszym i drugim roku życia (por. np. Smith, Landry, Swank, 2000).

Autorzy terminu KR używają go w liczbie pojedynczej, choć wobec dziecka w wieku przedszkolnym wyróżniają trzy elementy KR. Ich propozycja takiego używania konstruktu ma charakter konceptualny i powstała na podstawie analizy literatury, czyli zarówno teorii, jak i wyników badań empirycznych. Choć badacze powołują się na dane wskazujące na istotność tych poszczególnych elementów rodzicielskich oddziaływań dla osiągania pewnych, istotnych dla kultury zachodniej celów socjalizacyjnych, to dopiero przyszłe badania pozwolą sprawdzić, czy taka trójskładnikowa struktura jest trafna także w odniesieniu do innych spodziewanych rezultatów rozwojowych u dziecka i w ramach innych niż zachodni kręgach kulturowych.

Opisując konstrukt KR, warto podkreślić również, że jeśli mówimy o kompetencji rodzica, to definiujemy oddziaływania rodziców na dziecko w kategoriach pewnej sprawności, umiejętności, a nie stylu czy postawy. Wydaje się, że rodzicielską kompetencję można rozpatrywać jako pewien rodzaj kompetencji społecznej. Zgodnie z definicją Anny Matczak kompetencje społeczne to ,złożone umiejętności warunkujące efektywność radzenia sobie w określonego typu sytuacjach społecznych, nabywane przez jednostkę w toku treningu społecznego" (2007, s. 7). Miernikiem posiadanych przez jednostkę społecznych kompetencji jest poziom efektywności jej funkcjonowania w społecznych sytuacjach, do których zalicza się między innymi kontekst tworzenia relacji interpersonalnych (Maxim, Nowicki, 2003; Spitzberg, Cupach, 1989). Jak się wydaje, na proces wychowywania dziecka składa się wiele powtarzających się społecznych sytuacji, a efektywnemu funkcjonowaniu $\mathrm{w}$ ich obrębie sprzyjają pewne posiadane przez rodziców umiejętności, które jednocześnie mogą w czasie tych społecznych sytuacji być kształtowane i ulegać zmianom.

Ważnym rozwojowym rezultatem KR jest stworzenie i podtrzymywanie zmieniającej się relacji z dzieckiem. Już Józef Rembowski (1972) 
podkreślał, że ustosunkowanie się rodziców do dziecka jest wykształcane podczas pełnienia funkcji rodzicielskich, tak więc rodzicielstwo można uznać za szczególnego rodzaju społeczny trening, w ramach którego rodzice rozwijają swoją KR. Jak można zauważyć, wyróżnione przez Tetiego i Huang (2004) trzy komponenty KR wobec dziecka w okresie średniego dzieciństwa częściowo pokrywają się z przynajmniej dwoma elementami konsekwentnie przywoływanymi jako najistotniejsze składowe zarówno postaw rodzicielskich, jak i stylów wychowania. Podobnie jak styl i postawa KR obejmuje afekt (ciepło) i kontrolę (dyscyplinę, wymagania), ale w odróżnieniu od stylu i postawy zawiera również ważny komponent jakości komunikacji. Co więcej, w KR wszystkie te składniki są ujmowane pozytywnie i wtedy ich przejawy są zgodne z kulturowo określonymi celami socjalizacyjnymi i są dopasowane do wieku dziecka.

Warto zaznaczyć, że konstrukt KR koresponduje $\mathrm{z}$ innymi terminami określającymi oddziaływania rodzicielskie, takimi jak na przykład aktywne rodzicielstwo (Hoghughi, 2004), zaangażowane rodzicielstwo (Bakiera, 2013, 2017, 2018) czy rodzicielstwo bliskości (attachment parenting) (Sears, Sears, 2001). Na aktywne rodzicielstwo (active parenting) składa się rozpoznawanie stanów dziecka, adekwatna ich interpretacja i odpowiednio dopasowany do nich sposób działania. Pisząc o kompetencji rodzicielskiej, Teti i Huang również zwracają uwagę na znaczenie dopasowywania oddziaływań rodziców do dziecka. Trudno sobie wyobrazić kompetentne zachowanie rodzica, które nie zawierałoby w sobie uwzględniania stanów dziecka. Zachowanie rodzica pozbawione takich charakterystyk nie pozwoliłoby na wykształcenie $\mathrm{z}$ dzieckiem więzi emocjonalnej (składnik rodzicielskiego ciepła), na zbudowanie jasnego przekazu odnośnie do pożądanych sposobów zachowania się z uwzględnieniem zasad responsywnego dialogu (składnik jakości komunikacji), jak również na skuteczne dyscyplinowanie. Z pewnością również konstrukt zaangażowanego rodzicielstwa (involved parenting), którego istota wyraża się w skłonności rodzica do długotrwałego skoncentrowania aktywności i przeżyć z nią związanych na roli matki lub ojca
(Bakiera, 2013, 2017, 2018), blisko koresponduje z KR. Kompetencja rodzicielska wobec dzieci w różnych okresach rozwojowych wyraża się w adekwatnym dopasowywaniu rodzica do zmieniających się potrzeb i możliwości dziecka, a więc można powiedzieć, że aby zachować KR $\mathrm{z}$ upływem czasu, rodzic musi pozostawać niezmiennie zaangażowany w swoją rolę. Można także twierdzić, że między konstruktem KR a rodzicielstwem bliskości (Sears, Sears, 2001) jest wiele podobieństw. W wyniku postępującej globalizacji do repertuaru praktyk wychowawczych rodziców pochodzących z zachodniego kręgu kulturowego określających siebie mianem ,,rodziców bliskości” weszły zachowania charakterystyczne bardziej dla rodziców spoza tego kręgu. Należą do nich między innymi karmienie dziecka na żądanie czy spanie wspólnie z dzieckiem. Rodzicielstwo bliskości opiera się na przekonaniu rodziców, że właśnie takie praktyki są, z punktu widzenia rozwoju dziecka, lepsze niż te ogólnie przyjęte. Można więc powiedzieć, że sama znajomość „niezachodnich” praktyk wychowawczych jest wynikiem przenikania się kultur, ale ich stosowanie wynika z osobistych przekonań rodziców odnośnie do tego, co dla dziecka najbardziej właściwe, a co często pozostaje w sprzeczności z powszechnie przyjętymi praktykami „zachodnimi”. Jeśli zaś na kompetencję rodzicielską składają się takie oddziaływania rodzica, które w konsekwencji mają doprowadzić do osiągnięcia przez dziecko rezultatów rozwojowych istotnych z punktu widzenia danej kultury, to można by sądzić, że rodzicielstwo bliskości w zachodniej kulturze, które wyraża się w praktykowaniu na przykład spania wspólnie z dzieckiem, może stanowić przejaw rodzicielskiej niekompetencji, gdyż przynajmniej potencjalnie zbyt długie trwanie takiej praktyki doprowadza do rezultatów sprzecznych z wymogami kulturowymi (np. wykształcenia u dziecka dużej zależności od rodzica zamiast niezależności cenionej w kulturze zachodniej) (Green, Groves, 2008). Jeśli jednak przyjmiemy, że celem, który przyświeca rodzicom, jest nawiązanie mocnej, nacechowanej pozytywnymi emocjami więzi z dzieckiem, a zwłaszcza z niemowlęciem, ta niespójność zostaje uchylona. Ukształtowanie relacji emo- 
cjonalnej z dzieckiem może być uznane za podstawowe dążenie oddziaływań rodzicielskich, bez względu na konstrukt, którego użyjemy, aby je wyróżnić i opisać. Przede wszystkim ten właśnie cel stanowi o podobieństwie KR i rodzicielstwa bliskości. Wydaje się, że wszelkie praktyki wychowawcze mają większą szansę powodzenia, kiedy u ich podłoża leży właśnie taka pozytywna relacja ${ }^{5}$.

\section{PODSUMOWANIE}

Na zakończenie warto podkreślić jeszcze dwie ważne zalety badania KR, a nie postawy rodzicielskiej czy stylu wychowania. Po pierwsze, jeśli przyjąć, że kompetencja jest pewną sprawnością czy umiejętnością wyrażającą się w interakcji i komunikacji z dzieckiem, to może ona zarówno ulegać naturalnym zmianom, jak i być kształtowana oraz doskonalona poprzez trening. Właśnie uwzględnienie elementu komunikacji z dzieckiem i opisywanie jej jako jednej z integralnych składowych KR wydaje się cennym wkładem twórców tego konstruktu. Po drugie, pisząc o KR jako pewnej zmieniającej się i podlegającej treningowi społecznej sprawności, można zachować obiektywną i niezaangażowaną postawę oraz abstrahować od wartościowania tego, co jest „dobrym”, a co „złym” rodzicielstwem. Badacze postaw posługują się określeniami takimi jak postawa „pozytywna” i ,negatywna”, ,właściwa” i ,niewłaściwa", a mówiąc o stylach, odwołują się do „kochającego" i „niekochającego” (Ryś, 2009). Takie podejście ma charakter silnie wartościujący. Postawy i style rozumiane są jako swego rodzaju charakterystyki rodzica, względnie trwałe, a zatem potencjalnie trudne do zmiany. Klasyfikowanie danej postawy rodzica jako „niewłaściwej” może sprzyjać etykietowaniu rodzica i uproszczonemu rozumowaniu, które nie uwzględnia ani indywidualnych właściwości dziecka, ani oddziaływania dziecka na rodzica. Może to również prowadzić u rodziców do negatywnej samooceny w pełnionej roli lub obronnej postawy w relacji z psychologiem, do którego zwracają się po pomoc, a nie do wzbudzenia motywacji, aby opanować umiejętności, czyli właśnie kompetencje, istotne w jego relacji z dzieckiem. A zatem z punktu widzenia społecznych konsekwencji posługiwania się terminami „postawa”, ,styl” również znacznie lepiej będzie, gdy zamiast nich użyjemy terminu ,kompetencja rodzica”, a wykorzystanie przez rodzica asymetrycznej pozycji wynikającej z przewagi władzy, sił i umiejętności będziemy nazywać przemocą, a nie ,postawą skrajnej awersji rodzica wobec dziecka" (Bakiera, 2018). Możemy wtedy jako psychologowie zachęcać rodziców do opanowania pewnych umiejętności, a zarazem nie zgadzamy się na nazywanie zachowań przemocowych oddziaływaniami rodzicielskimi.

Dodać należy, że choć Teti i Huang (2004), pisząc o KR, zaznaczają jej podobieństwo do autorytatywnego stylu dyscyplinowania (por. Baumrind, 1971, 1991), to podkreślają jednocześnie, że dana osoba może albo zachowywać względną stabilność, albo odznaczać się brakiem stabilności w zakresie swojej rodzicielskiej kompetencji z upływem czasu (por. np. Smith i in., 2000). Tak więc choć o rodzicielskiej kompetencji również można myśleć jako o pewnej charakterystyce rodzica, to jest ona jednocześnie konstruktem bardziej od postawy czy stylu dynamicznym, czymś, co można ćwiczyć, doskonalić, stymulować. W ten sposób zamiast nazywać jakiegoś rodzaju oddziaływania ,właściwymi” czy „niewłaściwymi”, psychologia jako nauka może pomóc wskazać, które aspekty kompetencji rodzicielskiej zmieniają się w zależności od wieku dziecka w danej kulturze oraz w jaki sposób można wspierać tę zmianę na przykład poprzez celową interwencję. Nie oznacza to jednocześnie, że styl wychowawczy czy postawa rodzicielska nie mogą również ulegać zmianie. Wydaje się jednak, że traktowanie oddziaływań rodzicielskich w kategoriach kompetencji daje w tym zakresie większe możliwości. Po pierwsze, społeczny odbiór „niewłaściwej” postawy rodzicielskiej czy „niekochającego” stylu wychowania jest bardziej negatywny w porównaniu ze stwierdzeniem „niskiej kompetencji” w jakimś zakresie. Styl czy postawa określa bowiem całość ustosunkowania się rodzica wobec dziecka i jest podstawą zachowań wobec niego, stanowiąc ogólniejszą niż kompetencja charaktery- 
stykę tej relacji. Dlatego ocena tak ujmowanych oddziaływań ma bardziej globalny charakter i jeśli jest negatywna, potencjalnie może mieć nawet stygmatyzujący wydźwięk. Po drugie, jeśli przyjmować, że kompetencja składa się $\mathrm{z}$ subkompetencji, to $\mathrm{w}$ kontakcie $\mathrm{z}$ rodzicem można podkreślać, że na przykład tylko jedną z nich należy rozwijać, jednocześnie uwypuklając jego pozostałe wysokie subkompetencje. Postulując zmianę terminologii oraz zachęcając psychologów rozwojowych i wychowawczych do posługiwania się terminem „,kompetencja” zamiast terminami ,styl/postawa” - uważamy, że w samej psychologii spowoduje to szersze spojrzenie na zagadnienie oddziaływań wychowawczych, a społecznie - może dać rodzicom większą szansę na aktywne kształtowanie swojej wiedzy i umiejętności. Zbiorcze porównanie konstruktów postawy rodzicielskiej, stylu wychowania oraz KR przedstawiono w tabeli 1.

Tabela 1. Podsumowanie konstruktów odnoszących się do oddziaływań rodzicielskich

\begin{tabular}{|c|c|c|c|}
\hline Konstrukt & Postawa rodzicielska & $\begin{array}{c}\text { Styl rodzicielski/ } \\
\text { wychowania }\end{array}$ & $\begin{array}{c}\text { Kompetencja } \\
\text { rodzicielska }\end{array}$ \\
\hline Definicja & \begin{tabular}{|l|} 
Nabyta struktura po- \\
znawczo-dążeniowo- \\
-afektywna lub całościo- \\
wa forma ustosunko- \\
wania rodziców wobec \\
dziecka, która wyznacza \\
ich zachowanie wobec \\
dziecka
\end{tabular} & $\begin{array}{l}\text { Konstelacja postaw ro- } \\
\text { dzica wobec dziecka, } \\
\text { rodzicielska koncepcja } \\
\text { wychowania, która two- } \\
\text { rzy emocjonalny klimat } \\
\text { ich relacji oraz określa } \\
\text { sposoby wywierania } \\
\text { wpływu na dziecko }\end{array}$ & $\begin{array}{l}\text { Oddziaływania rodzi- } \\
\text { cielskie nakierowane na } \\
\text { osiąganie przez dziecko } \\
\text { określonych rezultatów } \\
\text { rozwojowych, cenionych } \\
\text { w danej kulturze i wy- } \\
\text { nikających z jego wieku } \\
\text { (fazy rozwojowej) }\end{array}$ \\
\hline $\begin{array}{l}\text { Ilość składników } \\
\text { wymiarów }\end{array}$ & $\begin{array}{l}\text { Trzy składniki (np. Plo- } \\
\text { pa, 2011) }\end{array}$ & $\begin{array}{l}\text { Zmienna w zależności } \\
\text { od opracowania, np. dwa } \\
\text { (Maccoby, Martin, 1983); } \\
\text { cztery (Baumrind, 1991); } \\
\text { trzy (Martowska, 2012) }\end{array}$ & $\begin{array}{l}\text { Trzy składniki: } \\
\text { rodzicielskie ciepło, } \\
\text { kontrola oraz jakość ko- } \\
\text { munikacji (Teti, Huang, } \\
2004 \text { ) }\end{array}$ \\
\hline $\begin{array}{l}\text { Przykładowe } \\
\text { narzędzia }\end{array}$ & $\begin{array}{l}\text { - Skala Postaw Ro- } \\
\text { dzicielskich (Plopa, } \\
\text { 2008); } \\
\text { - Kwestionariusz Sto- } \\
\text { sunków między Ro- } \\
\text { dzicami a Dziećmi } \\
\text { (PCRQ) (Roe, Siegel- } \\
\text { man, 1963, autoryzo- } \\
\text { wany przekład S. Ko- } \\
\text { walski, 1984) }\end{array}$ & $\begin{array}{l}\text { - The Parenting Styles } \\
\text { and Dimensions Ques- } \\
\text { tionnaire (Robinson, } \\
\text { Mandleco, Olsen, Hart, } \\
\text { 2001); } \\
\text { - Parenting Attitudes In- } \\
\text { ventory (Vinden, 2001); } \\
\text { - Kwestionariusz Styl } \\
\text { Wychowania w Rodzi- } \\
\text { nie Własnej (Ryś, 2009); } \\
\text { - Kwestionariusz Auto- } \\
\text { rytetu Rodzicielskiego } \\
\text { (Buri, 1991) }\end{array}$ & $\begin{array}{l}\text { Do badania: } \\
\text { - emocjonalnej dostęp- } \\
\text { ności (Biringen, 2000); } \\
\text { - rodzicielskiej wraż- } \\
\text { liwości (Pianta i in., } \\
\text { 1989); } \\
\text { - kontroli (Zahn-Waxler, } \\
\text { Iannotti, Cummings, } \\
\text { Denham, 1990); } \\
\text { - komunikacji (np. Den- } \\
\text { ham i in., 2000) }\end{array}$ \\
\hline $\begin{array}{l}\text { Uwzględnianie wieku } \\
\text { dziecka jako charakte- } \\
\text { rystyki istotnej dla kon- } \\
\text { ceptualizacji i operacjo- } \\
\text { nalizacji pojęcia }\end{array}$ & $\begin{array}{l}\text { Oddziaływania uważane } \\
\text { są za zmienne, ale nie ma } \\
\text { to odzwierciedlenia w ba- } \\
\text { daniach / narzędziach }\end{array}$ & $\begin{array}{l}\text { Niezmienne oddziały- } \\
\text { wania }\end{array}$ & $\begin{array}{l}\text { Wyraźnie zdefiniowana } \\
\text { zmiana w składowych } \\
\text { kompetencji, która po- } \\
\text { wiązana jest z wiekiem } \\
\text { dziecka }\end{array}$ \\
\hline $\begin{array}{l}\text { Uwzględnianie wzajem- } \\
\text { ności oddziaływań w re- } \\
\text { lacji rodzic-dziecko }\end{array}$ & Nie & Nie & Tak \\
\hline $\begin{array}{l}\text { Poszukiwanie uwarun- } \\
\text { kowań vs konsekwencji } \\
\text { danych oddziaływań }\end{array}$ & $\begin{array}{l}\text { Przede wszystkim bada- } \\
\text { no konsekwencje postaw }\end{array}$ & $\begin{array}{l}\text { Przede wszystkim bada- } \\
\text { no konsekwencje stylów }\end{array}$ & $\begin{array}{l}\text { Badano zarówno uwa- } \\
\text { runkowania, jak i kon- } \\
\text { sekwencje składników } \\
\text { kompetencji }\end{array}$ \\
\hline
\end{tabular}

Źródło: opracowanie własne. 
Powyższe spostrzeżenia podzielają także inni badacze, podkreślający użyteczność opisywania rodzicielskich oddziaływań właśnie w ramach kompetencji jako pojęcia, które w przeciwieństwie do postawy czy stylu - bezpośrednio odnosi się do efektywności zachowań rodzicielskich oraz zakłada, że są to zachowania wyuczone i, co za tym idzie, możliwe do doskonalenia (Matczak, Jaworowska, 2017). W nowszych konceptualizacjach rodzicielskich oddziaływań można zauważyć przeniesienie akcentów ze względnie stałych dyspozycji jednostkowych rodzica na jego rzeczywiste, podlegające zmianom działania, o czym świadczą zarówno niedawno rozpoczęte projekty badawcze (Sikorska, 2015; Święcicka, 2013), jak i nowo tworzone narzędzia pomiarowe (Matczak, Jaworowska, 2017). Również trwające w naszym ośrodku prace nad stworzeniem adekwatnych narzędzi do pomiaru KR w jej trójskładnikowej postaci, zgodnie $\mathrm{z}$ rozumieniem Tetiego i Huang (2004), są pierwszym etapem badań (Jackiewicz, w przygotowaniu), których późniejsze cele będą aplikacyjne.

Podsumowując, podkreślmy, że celem niniejszej pracy było przedstawienie użyteczności konstruktu KR zgodnie z rozumieniem Tetiego i Huang (2004). Przywołując dwie najsilniej zarysowane tradycje ujmowania oddziaływań rodzicielskich w ramach postaw rodzicielskich oraz stylów wychowania, zestawiając je zarazem z konstruktem KR, starano się wykazać, iż wszystkie one odwołują się do tych samych składników (rodzicielskie ciepło oraz kontrola), lecz - jak się wydaje - jedynie KR pozbawiona jest niektórych, widocznych w innych konstruktach ograniczeń, związanych przede wszystkim $\mathrm{z}$ ich jednokierunkowym, statycznym, abstrahującym od kulturowych uwarunkowań i czasem nawet wartościującym charakterem. Rozumienie KR jako sprawności dynamicznej, ujawniającej się w dwupodmiotowej interakcji z dzieckiem w określonej fazie rozwojowej, pozwala na zmianę akcentów i zdystansowanie się od tradycyjnego ujmowania relacji wychowawczej jako jednokierunkowej, tj. od rodzica do dziecka. Podkreślona została również konieczność uwzględnienia kulturowego zaplecza w rozważaniach nad wychowywaniem, a ujmowanie KR jako pewnego rodzaju kompetencji społecznej pozwala spojrzeć na nią nie jako na względnie trwałą dyspozycję jednostkową, ale jako na umiejętność podlegającą rozwijaniu i doskonaleniu. Choć trudno nasze rozważania uznać za wyczerpujące, mamy nadzieję, że zachęcą one czytelników do refleksji nad tym, jak precyzyjnie i zarazem wystarczająco szeroko definiować rodzicielskie oddziaływania.

\section{PRZYPISY}

1 Praca finansowana z projektu NCN „Stabilność i ciągłość w rozwoju teorii umysłu w średnim dzieciństwie. Trajektorie i predyktory rozwoju" (2015/19/B/HS6/01252) oraz ze środków DSC na zadania służące rozwojowi młodej kadry naukowej oraz uczestników studiów doktoranckich na Wydziale Filozoficznym UJ w roku 2017.

W tym miejscu warto podkreślić, że wnikliwiej analizując wymiar wymagań, czyli stawiania granic i kontroli zachowania dziecka, oraz wymiar autonomii, czyli dawania dziecku swobody (tzw. rozumnej swobody w ujęciu Ziemskiej, 1973), która nie oznacza ani braku wymagań, ani sztywności w ich egzekwowaniu, faktycznie odnosimy się do opisania jednego wymiaru postawy, która nie jest ani nadmiernie wymagająca, ani nadmiernie chroniąca (Plopa, 2011). Wymiar ten, na potrzeby dalszych rozważań, nazwijmy rodzicielską kontrolą.

Należy również dodać, że Skala Postaw Rodzicielskich Plopy w wersji dla rodziców oraz dla młodzieży (2008) ma dobre właściwości psychometryczne i cieszy się dużą popularnością wśród polskich badaczy (np. Liberska, Farnicka, 2015; Ogińska-Bulik, Zadworna-Cieślak, 2013; Suwalska-Barancewicz, Malina, 2013).

$4 \quad$ Jak się wydaje, największą popularność w polskich badaniach zdobyły narzędzia skonstruowane na podstawie typologii Baumrind (Buri, 1991; por. np. Cierpka, Wierzbicka, 2013) oraz typologii systemów rodzinnych Davida Fielda (1996; Ryś, 2009; por. np. Walęcka-Matyja, Kurpiel, 2015). 
5 Ograniczamy porównanie konstruktu KR do trzech innych konstruktów, zdając sobie jednocześnie sprawę, że można go opisywać w relacji także do jeszcze innych kategorii stosowanych w odniesieniu do oddziaływań rodzicielskich, jak na przykład uważne rodzicielstwo (attentive parenting) (np. Kabat-Zinn, Kabat-Zinn, 2008) czy opiekuńcze rodzicielstwo (nurturant parenting) (Curtner-Smith, Bennett, O'Rear, 1995).

\section{BIBLIOGRAFIA}

Ainsworth M.D.S., Blehar M.C., Waters E., Wall S. (1978). Patterns of Attachment: A Psychological Study of the Strange Situation. Hillsdale, NJ: Lawrence Erlbaum Associates.

Ambert A.M. (1992). The Effect of Children on Parents. New York: Haworth Press.

Bakiera L. (2013). Zaangażowane rodzicielstwo a autokreacyjny aspekt rozwoju dorostych. Warszawa: Difin SA.

Bakiera L. (2017). Doświadczanie rodzicielstwa i doświadczenia rodzicielskie. Propozycja konceptualizacji. Psychologia Rozwojowa, 22(2), 15-31.

Bakiera L. (2018). Styl realizacji rodzicielstwa a społeczny kontekst funkcjonowania współczesnych rodziców. W: B. Harwas-Napierała, L. Bakiera (red.), Oblicza współczesnej rodziny, 31-66. Poznań: Wydawnictwo Naukowe UAM.

Barnard K.E. (1994). What the NCAST feeding scale measures. W: G.S. Summer, A. Spietz (red.), NCAST: Caregiver/Parent-Child Interaction Manual, 98-121). Seattle: WAL University of Washington NCAST Publications.

Baumrind D. (1968). Authoritarian versus authoritative parental control. Adolescence, 3, 255-272.

Baumrind D. (1971). Harmonious parents and their preschool children. Developmental Psychology, 4, 99-102.

Baumrind D. (1980). New direction in socialization research. American Psychologist, 35, 639-652.

Baumrind D. (1991). Parenting styles and adolescent development. W: J. Brooks-Gunn, R. Lerner, A.C. Petersen (eds.), The Encyclopedia of Adolescence, 746-758. New York: Garland.

Baumrind D. (1993). Parents and children. W: B. Yorburg (ed.), Family Relationships, 287-308. New York: St. Martin's Press.

Belsky J., Robins E., Gamble W. (1984). The determinants of parenting: Toward a contextual theory. W: M. Lewis, L. Rosenblum (eds.), Beyond the Diad: Social Connections, 251-280. New York: Plenum.

Biringen Z. (2000). Emotional availability: Conceptualization and research findings. Americal Journal of Orthopsychiatry, 70, 104-114.

Borecka-Biernat D. (1995). Nieśmiałość i agresja nastolatków a styl wychowania w rodzinie. Problemy Rodzi$n y, 5,45-46$.

Bornstein M.H., Tamis-Lemonda C.S., Hahn C.S., Haynes O.M. (2008). Maternal responsiveness to young children at three ages: Longitudinal analysis of a multidimensional, modular, and specific parenting construct. Developmental Psychology, 44(3), 867-874.

Bronfenbrenner U. (1979). The Ecology of Human Development. Cambridge: Harvard University Press.

Bronfenbrenner U. (1993). Ecological models of human development. W: M. Gauvain, M. Cole (eds.), Readings on the Development of Children, 37-43. New York: Freeman.

Brzozowski P. (1988). CRPBI - Kwestionariusz do badania zachowania się rodziców w percepcji dzieci. W: K. Pospiszyl (red.), Z badań nad postawami rodzicielskimi, 9-20. Lublin: UMCS.

Buri J.R. (1991). Parental authority questionnaire. Journal of Personality Assessment, 57, 110-119.

Cierpka A., Wierzbicka J. (2013). Samoocena młodych dorosłych a style wychowania w rodzinie pochodzenia. Psychologia Wychowawcza, 46(4), 80-92.

Coplan R.J., Reichel M., Rowan K. (2009). Exploring the associations between maternal personality, child temperament, and parenting: A focus on emotions. Personality and Individual Differences, 46(2), 241-246.

Curtner-Smith M.E., Bennett T.L., O’Rear M.R. (1995). Fathers' occupational conditions, values of self-direction and conformity, and perceptions of nurturant and restrictive parenting in relation to young children's depression and aggression. Family Relations, 44(3), 299-305.

Darling N., Steinberg L. (1993). Parenting style as a context: An integrative model. Psychological Bulletin, 113(3), 487-496. 
Denham S.A., Workman E., Cole P.M., Weissbrod C., Kendziora K.T., Zahn-Waxler C. (2000). Prediction of externalizing behavior problems from early to middle childhood: The role of parental socialization and emotion expression. Development and Psychopathology, 12, 23-45.

Dryll E. (1995). Trudności wychowawcze. Analiza interakcji matka-dziecko w sytuacjach konfliktowych. Warszawa: Oficyna Wydawnicza Wydziału Psychologii Uniwersytetu Warszawskiego.

Field D. (1996). Osobowości rodzinne. Warszawa: Logos.

Fletcher A.C., Walls J.K., Cook E.C., Madison K.J., Bridges T.H. (2008). Parenting style as a moderator of associations between maternal disciplinary strategies and child well-being. Journal of Family Issues, 29, $1724-1744$.

Galinsky E. (1987). The Six Stages of Parenthood. Boston: Addison-Weasley.

Gauvain M., Perez S.M., Beebe H. (2013). Authoritative parenting and parental support for children's cognitive development. W: R.E. Larzelere, A.S. Morris, A.W. Harrist (eds.), Authoritative Parenting: Synthesizing Nurturance and Discipline for Optimal Child Development, 211-233. Washington, DC: American Psychological Association Press.

Golombok S. (2015). Modern Families: Parents and Children in New Family Forms. Cambridge: Cambridge University Press.

Green K.E., Groves M.M. (2008). Attachment parenting: An exploration of demographics and practices. Early Child Development and Care, 178(5), 513-525.

Grusec J.E. (2011). Socialization Processes in the family: Social and emotional development. Annual Review of Psychology, 62, 243-269.

Grusec J.E., Davidov M. (2010). Integrating different perspectives on socialization theory and research: a domain-specific approach. Child Development, 81(3), 687-709.

Grusec J.E., Davidov M. (2015). Analyzing socialization from a domain-specific perspective. W: J.E. Grusec, P.D. Hastings (eds.), Handbook of Socialization. Theory and Research. New York: Guilford Press.

Grusec J.E., Goodnow J.J. (1994). Impact of parental discipline methods on the child's internalization of values: A reconceptualization of current points of view. Developmental Psychology, 30(1), 4-19.

Hart C.H., DeWolf D.M., Wozniak P., Burts D.C. (1992). Maternal and paternal disciplinary styles: Relations with preschoolers' playground behavioral orientations and peer status. Child Development, 63, 879-892.

Hart C.H., Ladd G.W., Burleson B.R. (1990). Children's expectations of the outcomes of social strategies: Relations with sociometric status and maternal disciplinary styles. Child Development, 61, 127-137.

Hoffman M.L. (1994). Discipline and internalization. Developmental Psychology, 30, 26-28.

Hoghughi M. (2004). Parenting. An introduction. W: M. Hoghughi, N. Long (eds.), Handbook of Parenting. Theory and Research for Practice, 1-18. Thousand Oaks, London, New Delhi: SAGE Publications.

Jackiewicz M. (w przygotowaniu). Rola kompetencji rodzicielskiej w kształtowaniu się dojrzalszej teorii umystu u dzieci w średnim dzieciństwie.

Kabat-Zinn M., Kabat-Zinn J. (2008). Dary codzienności. Poradnik uważnego rodzicielstwa, przeł. M. Czakański. Warszawa: IPSI Press.

Kowalski S. (1984). Kwestionariusz stosunków między rodzicami a dziećmi M. Roe i M. Siegelmana. Warszawa: Wydawnictwo Radia i Telewizji.

Kowalski W.S. (1982). Percepcja postaw rodziców przez ich dzieci jako metoda diagnozy środowiska rodzinnego. W: M. Ziemska, A. Kwak (red.), Funkcjonowanie rodziny a problemy profilaktyki spolecznej i resocjalizacji, 59-68. Warszawa: Wydawnictwo UW.

Kuczkowski S. (1991). Przyjacielskie spotkania wychowawcze. Kraków: Wydawnictwo Apostolstwa Modlitwy. Leadbeater B., Raver C. (1995). The cognitive revolution in children's understanding of mind. Commentary. Human Development, 38(4-5), 190-193.

Liberska H. (2007). Kształtowanie się tożsamości a styl wychowania w rodzinie. W: B. Harwas-Napierała, H. Liberska (red.), Tożsamość a wspótczesność. Nowe tendencje i zagrożenia, 53-75. Poznań: UAM.

Liberska H., Farnicka M. (2015). Agresywność i zachowania agresywne młodzieży a percypowane przez nią postawy rodzicielskie. Perspektywa rozwojowa. Psychologia Rozwojowa, 20(4), 25-44.

Liberska H., Matuszewska M. (2014). Modele funkcjonowania rodziny. Style wychowania. W: I. Janicka, H. Liberska (red.), Psychologia rodziny, 116-139. Warszawa: Wydawnictwo Naukowe PWN. 
Maccoby E.E., Martin J.A. (1983). Socialization in the context of the family: Parent-child interaction. W: P.H. Mussen, E.M. Heterington (eds.), Handbook of Child Psychology: Vol 4. Socialization, Personality, and Social Development, 1-101. New York: John Wiley \& Sons.

Maliszewski N., Czyżewska M., Krejtz I. (2009). Postawy jawne a postawy ukryte jako wyznaczniki poznania i zachowań społecznych. W: M. Kossowska, M. Kofta (red.), Psychologia poznania społecznego, 183-201. Warszawa: Wydawnictwo Naukowe PWN.

Martowska K. (2012). Psychologiczne uwarunkowania kompetencji spolecznych. Warszawa: Wydawnictwo Liberi Libri.

Matczak A. (2007). Kwestionariusz Kompetencji Społecznych KKS. Podręcznik, wyd. 2 uzupełnione. Warszawa: Pracownia Testów Psychologicznych PTP.

Matczak A., Jaworowska A. (2017). Test Kompetencji Rodzicielskich. Warszawa: Pracownia Testów Psychologicznych Polskiego Towarzystwa Psychologicznego.

Maxim L.A., Nowicki S.J. (2003). Developmental associations between nonverbal ability and social competence. Facta Universitatis, 2, 745-758.

Morris A.S., Cui L., Steinberg L. (2013). Parenting research and themes: What we have learned and where to go next. W: R.E. Larzelere, A.S. Morris, A.W. Harrist (eds.), Authoritative Parenting: Synthesizing Nurturance and Discipline for Optimal Child Development, 35-88. Washington, DC: American Psychological Association.

Obuchowska I. (2009). Rodzice i style wychowania. Część 2. Remedium, 9, 6-7.

Ogińska-Bulik N., Zadworna-Cieślak M. (2013). Percepcja postaw rodzicielskich a osobowy wzrost po traumie u dzieci i młodzieży - ofiar wypadków drogowych. Psychologia Rozwojowa, 18(1), 57-68.

Olszewski K., Talik E., Oleś M. (2016). Martwienie się młodzieży w okresie dorastania a percepcja postaw rodzicielskich. Psychologia Rozwojowa, 21(3), 89-103.

Ostafińska-Molik B., Wysocka E. (2014). Style wychowania w rodzinie pochodzenia w percepcji młodzieży gimnazjalnej i ich znaczenie rozwojowe - próba teoretycznej i empirycznej egzemplifikacji. Przegląd Pedagogiczny, 2, 213-234.

Parke R.D., Buriel R. (2006). Socialization in the family: Ethnic and ecological perspectives. W: N. Eisenberg, W. Damon, R.M. Lerner (eds.), Handbook of child psychology: Vol. 3. Social, Emotional, and Personality Development, 429-504. Hoboken, NJ: Wiley.

Parke R.D., Clark-Stewart A. (2011). Social Development. New York, NY: Willey.

Peterson G.W., Peters D.F. (1983). Adolescents' construction of social reality: The impact of television. Youth and Society, 15, 67-85.

Pianta R.C., Sroufe L.A., Egeland B. (1989). Continuity and discontinuity in maternal sensitivity at 6, 24, and 42 months in a high-risk sample. Child Development, 60, 481-487.

Plopa M. (1987). Skala postaw rodzicielskich. Psychologia Wychowawcza, 5, 553-567.

Plopa M. (2008). Skala Postaw Rodzicielskich. Warszawa: Vizja Press \& It.

Plopa M. (2011). Psychologia rodziny: teoria i badania. Kraków: Oficyna Wydawnicza Impuls.

Pluta A. (1979). Młodzież i dom rodzinny. Warszawa: Nasza Księgarnia.

Przetacznik-Gierowska M., Włodarski Z. (1998). Psychologia wychowawcza. Warszawa: Wydawnictwo Naukowe PWN.

Putnam S.P., Sanson A.V., Rothbart M.K. (2002). Child temperament and parenting. W: M.H. Bornstein (red.), Handbook of Parenting: Vol. 1. Children and Parenting, 255-277. Mahwah, NJ: Erlbaum.

Rembowski J. (1972). Więzi uczuciowe w rodzinie: studium psychologiczne. Warszawa: Państwowe Wydawnictwo Naukowe.

Robinson C.C., Mandleco B., Olsen S.F., Hart C.H. (2001). The parenting styles and dimensions questionnaire (PSDQ). W: B.F. Perlmutter, J. Touliatos, G.W. Holden (red.), Handbook of Family Measurement Techniques: Vol. 3. Instruments \& Index, 319-321. Thousand Oaks: Sage.

Roe A., Siegelman M. (1963). A parent-child relations questionnaire. Child Development, 34, 355-369.

Ryś M. (1994). Konflikty w rodzinie. Niszcza czy budują? Warszawa: Centrum Metodyczne Pomocy Psychologiczno-Pedagogicznej MEN.

Ryś M. (2009). Systemy rodzinne. Metody badań struktury rodziny pochodzenia i rodziny własnej. Warszawa: Centrum Metodyczne Pomocy Psychologiczno-Pedagogicznej. 
Sameroff A. (2009). The Transactional Model of Development: How Children and Contexts Shape Each Other. Washington, DC: American Psychological Association.

Sears W., Sears M. (2001). The Attachment Parenting Book: A Commonsense Guide to Understanding and Nurturing Your Baby. Boston: Little, Brown and Company.

Sikorska M. (2015). Praktyki rodzicielskie we współczesnych polskich rodzinach - rekonstrukcja codzienności. https://projekty.ncn.gov.pl/index.php?s=10258 (dostęp: 28.04.2018).

Smith K.E., Landry S.H., Swank P.R. (2000). The influence of early patterns of positive parenting on children's preschool outcomes. Early Education and Development, 11, 147-169.

Spitzberg R.H., Cupach W.R. (1989). Handbook of Interpersonal Competence Research. New York: Springer-Verlag Inc.

Stemplewska-Żakowicz K. (2008). Diagnoza psychologiczna. Diagnozowanie jako kompetencja profesjonalna. Gdańsk: GWP.

Stephens G., Matthews D. (2014). The communicative infant from 0-18 months. The social-cognitive foundations of pragmatic development. W: D. Matthews (ed.), Pragmatic Development in First Language Acquistion, 13-36. Amsterdam: John Benjamin Publishing.

Super C.M., Harkness S. (1986). The developmental niche: a conceptualization at the interface of child and culture. International Journal of Behavioral Development, 9, 545-569.

Suwalska-Barancewicz D., Malina A. (2013). Stres i postawy rodzicielskie matek i ojców osób dorosłych z niepełnosprawnością intelektualną. Psychologia Rozwojowa, 18(2), 79-90.

Święcicka M. (2013). Praktyki rodzicielskie rodziców dzieci z objawami ADHD. Zwiazki z przekonaniami rodziców oraz obrazem zaburzenia dziecka. https://projekty.ncn.gov.pl/index.php?s=8092 (dostęp: 28.04.2018).

Teti D.M., Huang K.-Y. (2004). Developmental perspectives on parenting competence. W: D.M. Teti (ed.), Handbook of Research Methods in Developmental Science, 161-182. Malden, MA: Blackwell.

Tyszkowa M. (1985). Badania nad uspołecznieniem i osobowością dzieci jedynych i mających rodzeństwo. W: M. Tyszkowa (red.), Rozwój dziecka w rodzinie i poza rodzina, 9-68. Poznań: Wydawnictwo Naukowe Uniwersytetu im. Adama Mickiewicza w Poznaniu.

Van den Bulck J., Van den Bergh B.R.H. (2005). The child effect in media and communication research: A call to arms and an agenda for research. W: P.J. Kalbfleisch (ed.), Communication Yearbook: An Annual Review, 29, 35-47. Mahwah, NJ: Lawrence Erlbaum Associates.

Vinden P.G. (2001). Parenting attitudes and children's understanding of mind: A comparison of Korean American and Anglo-American families. Cognitive Development, 16, 793-809.

Walęcka-Matyja K., Kurpiel D. (2015). Satysfakcja z życia a poczucie skuteczności i styl wychowania w percepcji matek młodzieży z niepełnosprawnością. Psychologia Rozwojowa, 20(1), 75-89.

Walker-Barnes C.J., Mason C.A. (2001). Ethnic differences in the effect of parenting on gang involvement and gang delinquency: A longitudinal, hierarchical linear modeling perspective. Child Development, 72(6), 1814-1831.

Wojciszke B. (2011). Psychologia społeczna. Warszawa: Wydawnictwo Scholar.

Zahn-Waxler C., Iannotti R.J., Cummings E.M., Denham S.A. (1990). Antecedents of problem behaviors in children of depressed mothers. Development and Psychopathology, 2, 271-291.

Ziemska M. (1973). Postawy rodzicielskie. Warszawa: Wiedza Powszechna.

Ziemska M. (1986). Rodzina i dziecko. Warszawa: Państwowe Wydawnictwo Naukowe. 